Literary Modernism Series

Thomas F. Staley, Editor

\title{
Stoppard's Theatre
}




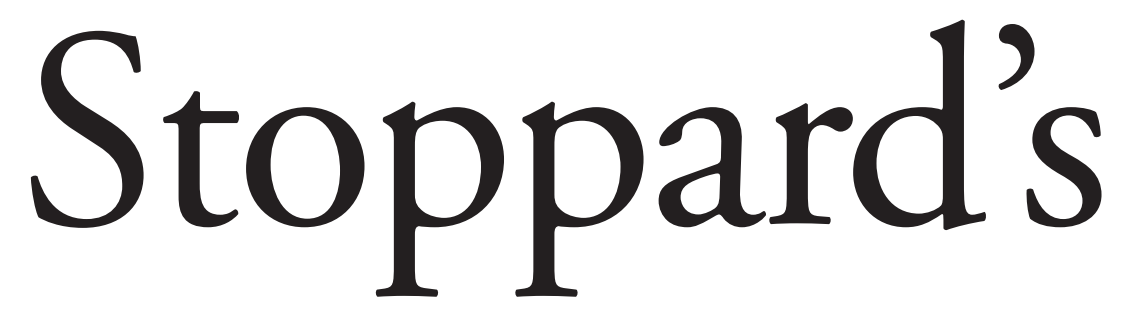

Finding

Order

amid

Chaos

University of

Texas Press,

Austin 


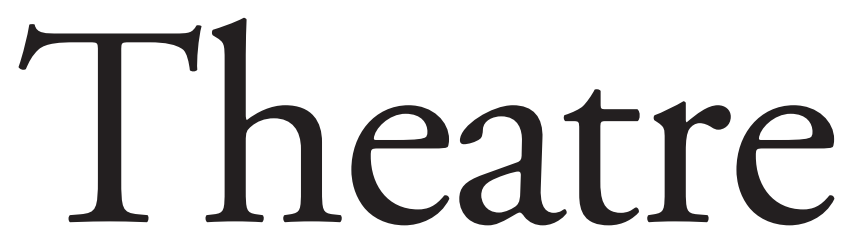

by John Fleming 
Copyright (C) 200I by the University of Texas Press

All rights reserved

Printed in the United States of America

First edition, 200I

Requests for permission to reproduce material from this work should be sent to Permissions, University of Texas Press, P.O.

Box 7819, Austin, TX 78713-7819.

(2) The paper used in this book meets the minimum requirements of ANSI/NISO Z39.48-I992 (RI997) (Permanence of Paper).

Library of Congress Cataloging-in-Publication Data

Fleming, John (John Patrick), 1965-

Stoppard's theatre : finding order amid chaos / by John

Fleming. — Ist ed.

p. $\quad \mathrm{cm}$. - (Literary modernism series)

Includes bibliographical references and index.

ISBN 0-292-72533-7 (alk. paper)

I. Stoppard, Tom-Criticism and interpretation. I. Title. II. Series.

PR6069.T6 z648 2OOI

$822^{\prime} \cdot 9 \mathrm{I} 4-\mathrm{dc} 2 \mathrm{I}$

2001027788 
To my family, with love and gratitude 
THIS PAGE INTENTIONALLY LEFT BLANK 